University for Business and Technology in Kosovo

UBT Knowledge Center

UBT International Conference

2017 UBT International Conference

Oct 27th, 4:45 PM - 6:15 PM

\title{
Factors Affecting Customer Loyalty in Retail Chain in Kosovo
}

Jonida Xhemaili

University for Business and Technology, jonida.xhema@ubt-uni.net

Nehat Ramadani

University for Business and Technology, nehat.ramdani@ubt-uni.net

Follow this and additional works at: https://knowledgecenter.ubt-uni.net/conference

Part of the Business Commons

\section{Recommended Citation}

Xhemaili, Jonida and Ramadani, Nehat, "Factors Affecting Customer Loyalty in Retail Chain in Kosovo" (2017). UBT International Conference. 246.

https://knowledgecenter.ubt-uni.net/conference/2017/all-events/246

This Event is brought to you for free and open access by the Publication and Journals at UBT Knowledge Center. It has been accepted for inclusion in UBT International Conference by an authorized administrator of UBT Knowledge Center. For more information, please contact knowledge.center@ubt-uni.net. 


\title{
Factors affecting Customer Loyalty in Retail Chain in Kosovo
}

\author{
Jonida Xhema $^{1}$, Nehat Ramadani ${ }^{2}$ \\ 1,2 UBT - Higher Education Institution Lagjja Kalabria, 10000 p.n., Prishtine, \\ Kosovo \{jonida.xhema ${ }^{1}$, nehat.ramadani $\left.{ }^{2}\right\} @$ ubt-uni.net
}

\begin{abstract}
Customer loyalty is at the core of human experience, which enables companies to gain competitive edge in currently tight markets. Customers aren't always easy to please, and now more than ever, they look for satisfactory services. When customers know that their needs are paramount to company's employees, returning to the retail is an easy decision. Satisfied customers are more likely to share their praise with others, thereby increasing the number of referrals the company receives. This article takes into amount the theoretical review of customer loyalty and its benefits. This article examines the applicability of customer's loyalty over a supermarket chain in Kosovo, Viva Fresh. This paper applies quantitative research to one hundred Viva's customers and analyzes were done with SPSS Statistics. The article concludes that customer satisfaction, trust and changing costs are main factors that affect customer loyalty in retail markets.
\end{abstract}

Keywords: Customer Loyalty, Supermarkets, Customer Satisfaction, Trust.

\section{Introduction}

As companies constantly focus on improving relationships with existing consumers, this research is important because its focus is to recognize factors influencing the creation of consumer loyalty in retail markets. This study aims to understand the affect that customer satisfaction, trust and switching costs have on customer loyalty. By reviewing the literature, initially, this study will explain different terms of customer loyalty and the two main concepts. Then, the focus will switch to the factors, which according to the theory have led to the creation of consumer loyalty. Finally, the study will show the results on the effect that factors such as customer satisfaction, trust and switching cost have on customer loyalty.

The key data is collected by surveying a sample of 100 VivaFresh Store customers. Through the results of these questionnaires it is suggested that the main factors that influence the creation of customer loyalty in retail markets are customer satisfaction and trust.

Hypothesis of this study are:

H1: Customer satisfaction has a positive influence on customer loyalty in retail markets.

$\mathrm{H} 2$ : Trust has a positive influence on customer loyalty in retail markets.

H3: Switching costs have a negative influence on customer loyalty in retail markets. 


\section{Literature Review}

\section{Customer Loyalty}

In the past, traditional marketing was more focused on attracting new consumers than maintaining existing ones and selling products rather than improving relationships. Now, customer loyalty and customer retention are the main goals of the most successful organizations. Loyalty to services is manifested through repetitive purchases, positive words and recommendations [1].

\section{Customer Loyalty Conceptualizations}

Customer loyalty is defined as a deep commitment to re-purchase a product or service in the future, regardless of different influences or marketing efforts that may cause changes. Customer loyalty has different dimensions. The two most important dimensions are the components of behavior and attitudes [6]. Initially, loyalty to the brand is defined as the number of purchases of a family to a mark within a certain time period [11]. There are three popular approaches when talking about consumer loyalty:

1) Behavioral approach involves changes in behavior of individuals, expressing strong intentions to re-purchase a product or service from a provider (measured by re-purchase goals, intent to change the brand and purchasing goals) [11]. Loyalty from a behavioral perspective is measured through proportion of purchases, the acquisition sequence and the probability of the acquisition [9]. Behavior model is highly controversial but is mostly supported by data. According to this approach, consumers buy the same brand, not because there is some strong faith or deep devotion to it, but because it is not worth spending time and encountering obstacles to seek another option [15].

2) The attitude based approach considers the emotional and psychological aspects of loyalty. A person may have a favorable attitude towards a hotel, and may recommend that hotel to others, but she/he will not stay at that hotel because it is too expensive for her/him. Commitment plays an important role in loyalty-based attitudes, as commitment reflects consumer appraisal towards consuming and decisions to maintain a long-term relationship [11].

3) Cognitive approaches include what an individual believes in relation to the relationship she/he has with the service provider. It is based on the evaluation of the attributes or the evaluation of the rewards and benefits associated with the service provider. Cognitive meters include first choice, price tolerance, exclusive consideration, identification with the service provider and willingness to pay more [11].

\section{Factors affecting Customer Loyalty}

The complexity of customer loyalty can be described by focusing on three important reasons: customer satisfaction, emotional devotion, calculated devotion. Consumer satisfaction is an overall performance appraisal of the company over a certain time. Consumer satisfaction derives from the quality of the product/service and price. Commitment can be emotional or calculated. Emotional commitment is an emotional factor that the customer creates with the retailer through repeated purchasing of the products, thus affecting the level of confidence. Calculated 
commitment, on the other hand, has more of a rational view based on economic dependence on a product by lack of choices or high brand replacement costs, creating loyalty [9].

According to studies of [2], [8], [7] and [13] main factors affecting customer loyalty are:

1) Customer Satisfaction;

2) Trust;

3) Switching Costs;

Customer Satisfaction:

Satisfaction is the most important factor which leads towards customer loyalty [4]. High customer satisfaction leads to improved loyalty and will also affect the reduction of customer sensitivity to competitive bids. Impact of consumer satisfaction on consumer loyalty is not the same in all industries. Loyal customers are not necessarily satisfied, but satisfied customers tend to be loyal [12]. Satisfaction is achieved by comparing the expectations to reality [8]. Satisfaction is a factor through which the customer understands whether her/his needs and desired have been achieved or exceeded [13].

Trust:

To achieve customer satisfaction and preservation, as well as long-term profit of the company, it is important to fulfill the promises [14]. Trust is needed to create long-term relationships with consumers and also trust is one of the most important factors that affecting customer loyalty [10]. Trust in a brand leads to loyalty and dedication to that brand, since trust creates relationships that are highly valued [7]. Belief is a positive factor of loyalty. It is constantly shown that there is a connection between trust to the seller, trust in the store and repetition of purchases [8]. Trust in products/services has positive effect for now and for the future, while consumer satisfaction does not have that dimension [5]. Perceived belief has a direct and positive effect on customer loyalty [3].

Switching Cost:

The switching cost is the cost involved when switching from one service provider to another [2]. The changing cost factor has direct impact on customer loyalty [5]. When the costs of changing the brand are high, it is more likely that consumer will remain loyal in terms of repeated purchasing [3]. A competitor would be more difficult to attract a loyal customer based on satisfaction than another loyal customer based on switching costs [13].

\section{Methodology}

This study is based on descriptive method and a quantitative analysis. The results were achieved through correlation, using SPSS Statistics. Questionnaires in a form of Likert Scale "1 - totally disagree" to "5 - totally agree" were delivered to a sample of 100 VivaFresh Store customers. The sample was selected by randomization and the only criteria were being a VivaFresh Store customer.

Customer's trust (independent variable) is analyzed in two different aspects: trust in VivaFresh Store towards fulfilling customer's obligations and trust in VivaFresh Store products/services. Customer satisfaction is analyzed in two different aspects: satisfaction with products/services of VivaFresh and customer's expectations. Switching costs are analyzed in two different aspects: switching costs in a matter of time and switching costs in a matter of money. Customer loyalty (dependent variable) is analyzed through positive word-of-mouth, recommendations on VivaFresh Store and first choice options. 


\section{Results}

On this study the dependent variable is customer loyalty (in retail markets) while independent variables are trust, switching cost and customer satisfaction. The analysis of the impact that independent variables have on dependent variables are done through Pearson correlation.

Firstly, according to table below (table 1) the correlation coefficient between trust and customer loyalty is 0.709 and by considering p-value $=0.000$, which is smaller than 0.05 , the hypothesis stating that trust positively influences customer loyalty in retail markets is acknowledged. Secondly, according to the table below, correlation coefficient between switching cost and customer loyalty is 0.530 and by considering $p$-value $=0.000$, which is smaller than 0.05 , the hypothesis stating that switching costs negatively affect customer loyalty in retail markets is not accepted. Finally according to table below the correlation coefficient between customer satisfaction and customer loyalty is 0.819 and by considering p-value $=0.000$, which is smaller than 0.05 , the hypothesis stating that customer satisfaction positively affects customer loyalty in retail markets is acknowledged.

Table 1. Correlation between variables

\begin{tabular}{|c|c|c|c|c|c|}
\hline & & Trust & $\begin{array}{c}\text { Switching } \\
\text { Cost }\end{array}$ & Satisfaction & $\begin{array}{l}\text { Customer } \\
\text { Loyalty }\end{array}$ \\
\hline $\begin{array}{l}\text { Pearson } \\
\text { Correlati } \\
\text { on }\end{array}$ & $\begin{array}{l}\text { Trust } \\
\text { Switching Cost } \\
\text { Satisfaction } \\
\text { Customer } \\
\text { Loyalty }\end{array}$ & $\begin{array}{c}1 \\
0.438 \\
0.711 \\
0.709\end{array}$ & $\begin{array}{c}0.438 \\
1 \\
0.369 \\
0.530\end{array}$ & $\begin{array}{c}0.711 \\
0.369 \\
1 \\
0.819\end{array}$ & $\begin{array}{c}0.709 \\
0.530 \\
0.819 \\
1\end{array}$ \\
\hline $\begin{array}{l}\text { Sig. 1- } \\
\text { tailed }\end{array}$ & $\begin{array}{l}\text { Trust } \\
\text { Switching Cost } \\
\text { Satisfaction } \\
\text { Customer } \\
\text { Loyalty }\end{array}$ & $\begin{array}{l}0.000 \\
0.000 \\
0.000\end{array}$ & $\begin{array}{l}0.000 \\
0.000 \\
0.000\end{array}$ & $\begin{array}{l}0.000 \\
0.000 \\
0.000\end{array}$ & $\begin{array}{c}0.000 \\
0.000 \\
0.000\end{array}$ \\
\hline $\mathrm{N}$ & $\begin{array}{l}\text { Trust } \\
\text { Switching Cost } \\
\text { Satisfaction } \\
\text { Customer } \\
\text { Loyalty }\end{array}$ & $\begin{array}{l}100 \\
100 \\
100 \\
100\end{array}$ & $\begin{array}{l}100 \\
100 \\
100 \\
100\end{array}$ & $\begin{array}{l}100 \\
100 \\
100 \\
100\end{array}$ & $\begin{array}{l}100 \\
100 \\
100 \\
100\end{array}$ \\
\hline
\end{tabular}




\section{Conclusions}

This research has shown that factors such as customer satisfaction and trust are crucial for companies since they can help on improving relationships with existing customers. Based on this research conducted with VivaFresh Store customers, it has been realized that the most important factor affecting the creation of loyalty is customer satisfaction. According to this study, customer satisfaction and trust have a strongly positive impact on customer loyalty.

In contrast to what is explained in the literature, that switching costs negatively affect customer loyalty, this study has shown that in retail markets (in our case VivaFresh Store), switching costs do not have a strong affect on customer loyalty. It is recommended that retail companies should focus on creating customer satisfaction and having trustworthy attitude towards customer, since this is how they can have loyal customers.

\section{References}

1. Abd-El-Salam, E.M., Shawky, A.Y., \& El-Nahas, T. (2013) The Impact of Corporate Image and Reputation on Service Quality, Customer Satisfaction and Customer Loyalty: Testing the Mediating Role. The Business \& Management Review, 3(2).

2. Akbar, M. M. (2013) Three Competing Models on Customer Loyalty in the Context of Mobile Subscribers. International Journal of Marketing Studies, 5(4).

3. Alibadi, B. M., Navid, B.J., \& Namamian, F. (2013) Design and Explain the Factors Affecting Customer Loyalty in Online Banking. International Research Journal of Applied and Basic Sciences, 4(9).

4. Anderson, E. W., Fornell, C., \& Lehmann, D. R. (1994) Customer Satisfaction, Market Share, and Profitability: Findings from Sweden. Journal of Marketing, 58(3), 53-66.

5. Aydin, S., Ozer, G., \& Arasil, O. (2005) Customer loyalty and the effect of switching costs as a moderator variable, a case in the Turkish mobile phone market. Marketing Intelligence and Planning. 23(1), 89-103.

6. Bae, Y. H. (2012) Three Essays on the Customer Satisfaction-Customer Loyalty Association. PhD thesis. University of Iowa.

7. Bilal, A. (n.d.) Determinants of Customer Loyalty and Proposing a Customer Loyalty model for the Banking Sector of Pakistan. Institute of Information Technology Abbottabad.

8. Bobâlcă, C. (2014) Determinants of Customer Loyalty. A Theoritical Approach. Journal of International Scientific Publications, 8.

9. Cecilia, K., Ladan, M., \& Maiju, R. (2007) Customer Loyalty Research: Can customer loyalty programs really build loyalty? Bachelor thesis. Jönköping University.

10. Doney, P. M., \& Cannon, J. P. (1997) An Examination of the Nature of Trust in BuyerSeller Relationships. Journal of Marketing, 61(2), 35-51.

11. Donnelly, M. (2009) Building Customer Loyalty: A Customer Experience Based Approach in a Tourism Context. Masters thesis. Waterford Institute of Technology.

12. Fornell, C. (1992). A national customer satisfaction barometer: the Swedish experience. Journal of Marketing, 56(1), 6-21. 
13. Khan, B. (2014). Factors Contributing to Customer Loyalty in Commercial Banking. International Journal of Accounting and Financial Reporting, 4(2).

14. Reichheld, F. F., \& Sasser, W. E. Jr. (1990). Zero defections: Quality comes to services. Harvard Business Review, 68(5).

15. Uncles, M.D., Dowling, G.R., \& Hammond, K. (2003). Customer Loyalty and Customer Loyalty Programs. Journal of Consumer Marketing, 20(4), 294-316. 